\title{
Ability of the aquatic fern Azolla to remove chemical oxygen demand and polyphenols from olive mill wastewater
}

\author{
By, Alba Ena*, Pietro Carlozzi, Benjamin Pushparaj, Raffaella Paperi, Silvia Carnevale \\ and Angelo Sacchi.
}
Consiglio Nazionale delle Ricerche, Istituto per lo Studio degli Ecosistemi, Sede distaccata di Firenze, Polo Scientifico, via Madonna del Piano,10 50019 Sesto F.no, Firenze, Italy.
Phone: +39 055 5225953; Fax +39 0555225920
E-mail: alba.ena@ ise.cnr.it

\section{RESUMEN}

Eficacia del helecho de agua Azolla para reducir la demanda química de oxígeno y los polifenoles del alpechín.

La eficacia del helecho de agua azolla para eliminar polifenoles y reducir la demanda química de oxígeno (DQO) de los alpechines obtenidos en el proceso de obtención tradicional y continuo del aceite de oliva, fue investigado mediante ensayos de filtración. Cinco conos secuenciales de Imhoff y cinco columnas secuenciales se rellenaron de biomasa de Azolla. En ambos experimentos, el filtrado procedente de la quinta extracción mostró una disminución en el contenido de polifenoles de $7650 \mathrm{mg} \mathrm{L}^{-1}$ a $3610 \mathrm{mg} \mathrm{L}^{-1}$ en el alpechín obtenido mediante el sistema tradicional y de $3852 \mathrm{mg} \mathrm{L}^{-1}$ a $1351 \mathrm{mg} \mathrm{L}^{-1}$ en el alpechín del sistema continuo. La demanda química de oxígeno del alpechín del sistema tradicional disminuyó de $110200 \mathrm{mg} \mathrm{L}^{-1}$ a $52400 \mathrm{mg}$ $\mathrm{L}^{-1}$ en y de $41600 \mathrm{mg} \mathrm{L}^{-1}$ a $2300 \mathrm{mg} \mathrm{L}^{-1}$ en el procedente del sistema continuo. Una proporción en peso 5:1 de alpechín: Azolla fue la óptima tanto para la reducción de los polifenoles como para la de la DQO. La eficiencia del tratamiento biológico con alfalfa se comparó con la obtenida con Azolla. Los resultados indicaron que el tratamiento con alfalfa no dio lugar a la reducción de los polifenoles ni de la DQO.

PALABRAS-CLAVE: Alpechín - Azolla - Demanda química de oxígeno - Polifenoles - Tratamiento biológico.

\section{SUMMARY}

Ability of the aquatic fern Azolla to remove chemical oxygen demand and polyphenols from olive mill wastewater.

We investigated the biofiltration ability of the aquatic fern Azolla to remove polyphenols and chemical oxygen demand (COD) from olive mill wastewater (OMWw) collected from the traditional (TS) and continuous (CS) extraction systems. Azolla biomass was packed into five sequential Imhoff cones and five sequential columns. In both experiments, the filtrates collected from the $5^{\text {th }}$ biofilter showed a decrease in polyphenol contents: from $7650 \mathrm{mg} \mathrm{l}^{-1}$ to $3610 \mathrm{mg} \mathrm{I}^{-1}$ in TS OMWw and from $3852 \mathrm{mg} \mathrm{l}^{-1}$ to $1351 \mathrm{mg} \mathrm{l}^{-1}$ in CS OMWw. The COD contents decreased from $110200 \mathrm{mg} \mathrm{L}^{-1}$ to 52400 $\mathrm{mg} \mathrm{L}^{-1}$ in TS OMWw and from $41600 \mathrm{mg} \mathrm{L}^{-1}$ to $2300 \mathrm{mg} \mathrm{L}^{-1}$ in CS OMWw. A 5:1 OMWw to Azolla-fresh-weight ratio was optimal for both polyphenol and COD removal.

The biofiltration ability of alfalfa was compared with that of Azolla, but the treatment with alfalfa did not result in the reduction of $\mathrm{COD}$ or polyphenols.
KEY-WORDS: Azolla - Biological treatment - Chemical oxygen demand - Olive mill wastewater - Polyphenols.

\section{INTRODUCTION}

The extraction and use of olive oil has been an integral part of Mediterranean culture for over 6000 years (Civantos, 1995; Tardàguila et al., 1996).

Olive oil is produced by two methods: the traditional system (TS) and the continuous system (CS). Highly pollutant wastewater is a by-product of both processing methods. Olive oil extraction involves an intensive consumption of water and produces large amounts of olive mill wastewater $(\mathrm{OMWw})$, the average volume ranging from 0.5 to $1.5 \mathrm{~m}^{3}$ per ton of processed olives (MonteolivaSanchez et al., 1996; Paredes et al., 1996).

The content of fresh organic matter in oil mill wastewater is an agricultural and environmental problem for olive oil-producing countries, since its effects on soil status and fertility, insect proliferation and groundwater contamination are more harmful than beneficial (Cox et al., 1996; Spandre and Dellomonaco, 1996).

OMWw contains high amounts of organic matter $\left(30-200 \mathrm{~kg} \mathrm{COD} \mathrm{m}^{-3}\right)$, with a COD/BOD 5 ratio between 2.5 and 5, which is considered poorly degradable (Lopez, 1992). The organic compounds in OMWw (sugars, polyphenols, tannins, polyalcohols, pectins and lipids), in association with its high $\mathrm{C} / \mathrm{N}$ ratio and low $\mathrm{pH}$, compromise the biological degradation process of soils (Marques, 2000) and can cause eutrophication when the wastewater is collected in basins with low exchange rates (closed gulfs, lakes, etc.).

The toxicity of OMWw is also due to its high content of phenolic compounds in a wide range of molecular weights (MW), from low-MW substituted phenols to complex high-MW phenolic compounds (Montedoro et al., 1992). During olive oil production, large quantities of phenols are released along with the wastewater, according to their partition coefficient. Phenolics are derivatives of benzene (cyclic derivatives in the case of polyphenols) with one or more hydroxyl groups associated with their ring. The 
dark color of the water is caused by polyphenols $(\mathrm{Pp})$ (Hamdi and Garcia, 1993) and depends on the type of olives processed and their ripening stage and on climatic conditions, as well as the technology used. However, despite their toxicity, polyphenols are considered the most interesting compounds in OMWw (Visioli et al., 1995), because of their potential use in the perfume and pharmaceutical industries.

A possible treatment of OMWw to recover valuable compounds like polyphenols would employ the aquatic fern Azolla as a biofilter. Dried Azolla biomass has already been used in the biosorption of a wide range of heavy metal concentrations from aqueous media (Sela and Tel-Or, 1988; CohenShoel et al., 2002). Pectin is an important polysaccharide constituent of Azolla cell walls, made up of fragments of polygalacturonic acid chains that interact with $\mathrm{Ca}^{2+}$ and $\mathrm{Mg}^{2+}$ ions to form a threedimensional polymer (Schols et al., 1989; Jauneau et al., 1997; Kamnev et al., 1998). Carlozzi et al. (1986) reported progress in the development of a culture technique suitable for growing Azolla spp. in mineral solutions without combined nitrogen or in the wastewater from a sugar-refinery.

Azolla biomass can be used as a biofertilizer or as a feed supplement for aquatic and terrestrial animals due to its protein, crude fiber and mineral contents (Lumpkin and Plunknet, 1980).

The aim of this study was to test the ability of Azolla (vegetable matrix) to reduce the phenol and organic matter contents in wastewaters from the two methods of oil production. This paper reports the results of laboratory experiments.

\section{EXPERIMENTAL AND METHODS}

\section{OMWw Pre-treatment}

Fresh OMWw were collected in January 2004 from two olive mills (TS, CS) near Florence (Italy). Table 1 shows the main characteristics of the two OMWw after centrifugation.

\section{Azolla cultivation}

The strain of Azolla filiculoides derives from the Botanical Institute of Naples, Italy. Since the 1980s, it has been preserved by the "Centro di Studio dei

Table 1

Chemical parameters of olive mill wastewater (OMWw) obtained by both the traditional (TS) and continuous (CS) processes.

\begin{tabular}{ccc}
\hline $\begin{array}{c}\text { Chemical } \\
\text { parameters }\end{array}$ & $\begin{array}{c}\text { OMWw } \\
\text { from TS }\end{array}$ & $\begin{array}{c}\text { OMWw } \\
\text { from CS }\end{array}$ \\
\hline $\begin{array}{c}\text { pH } \\
\text { Colour }\end{array}$ & 4.5 & 5.1 \\
COD $\left(\mathrm{mg} \mathrm{L}^{-1}\right)$ & $92000 \pm 2.4$ & $15.7 \pm 0.6$ \\
Total Polyphenols & $7360 \pm 290$ & $44400 \pm 800$ \\
$\left(\mathrm{mg} \mathrm{L}^{-1}\right)^{*}$ & & $4367 \pm 130$ \\
\hline
\end{tabular}

* expressed in gallic acid
Microrganismi Autotrofi" of Florence, which is now part of the Institute of Ecosystem Study of the Italian CNR. During the summer, the fern was grown outdoors, first in four mini-ponds of $4.0 \mathrm{~m}^{2}$ and later in a maxi-pond of $25 \mathrm{~m}^{2}$, in the following nutrient medium: $\mathrm{KCl}, 0.149 \mathrm{~g} \mathrm{I}^{-1} ; \mathrm{CaCl}_{2} .2 \mathrm{H}_{2} \mathrm{O}, 0.294 \mathrm{~g} \mathrm{I}^{-1}$; $\mathrm{KH}_{2} \mathrm{PO}_{4}, 0.054 \mathrm{~g} \mathrm{l}^{-1} ; \mathrm{MgSO}_{4} .7 \mathrm{H}_{2} \mathrm{O}, 0.197 \mathrm{~g} \mathrm{l}^{-1} ; 1 \mathrm{ml}$ $\mathrm{I}^{-1}$ of Hughes' minor nutrients (Fe-EDTA). The FeEDTA consisted of: EDTANa $\mathrm{Fe}_{2} 29.754 \mathrm{~g}+\mathrm{FeSO}_{4}$ $7 \mathrm{H}_{2} \mathrm{O}, 24.9 \mathrm{~g}$ (total volume $=1.0 \mathrm{l}$ ). During the experiments, the optimal planting density of $50 \mathrm{~g}$ (d.w.) $\mathrm{m}^{-2}$ was maintained (Carlozzi et al., 1986).

\section{Biofiltration experiments}

Before using Azolla as a biofilter, it was washed thoroughly with distilled water and left to drip dry.

Fresh Azolla biomass (200 g) was inserted and lightly packed into each of five sequential Imhoff cones and five sequential columns $(7 \mathrm{~cm}$ diameter and $35 \mathrm{~cm}$ height). The OMWw volumes $(1 \mathrm{~L})$ were introduced and maintained in contact with the fern biomass for $30 \mathrm{~min}$. The OMWw was then percolated slowly into the beaker and analyzed for the presence of COD (Chemical Oxygen Demand) and polyphenols.

Figures 1 and 2 show the five packed Imhoff cones (in series) and the five columns (in series) used as biofilters in the laboratory experiments.

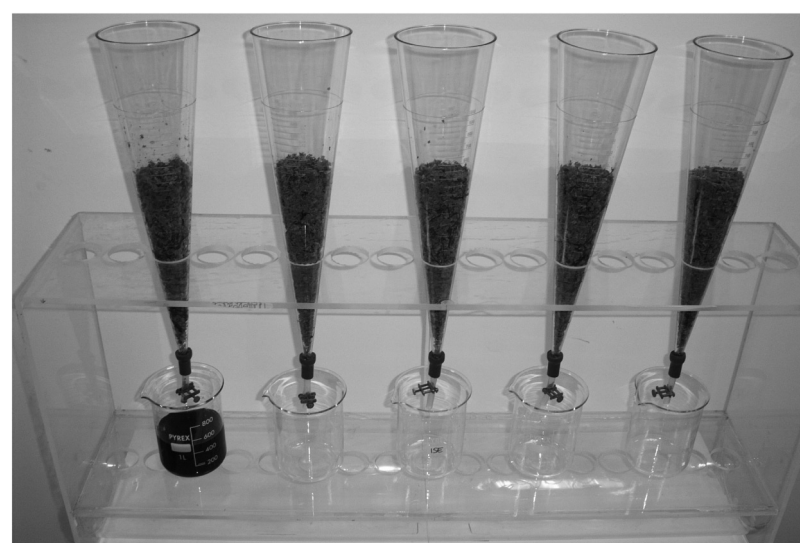

Figure 1

Azolla biomass packed inside Imhoff cones.

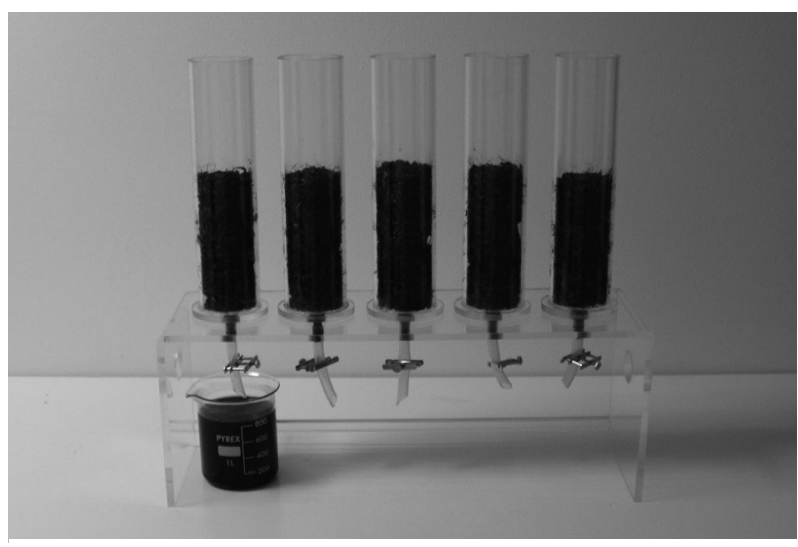

Figure 2

Azolla biomass packed inside columns. 


\section{Assay}

Decoloration: OMWw samples were collected, centrifuged (20 min at $4000 \mathrm{rpm}$ ) and diluted 1:50 (v:v), and the absorbance was recorded at $395 \mathrm{~nm}$ (Yesilada et al., 1997) with a Beckman DU 640 UV/Visible Spectrophotometer.

The COD concentration in the OMWw was determined with a HANNA C99 Multiparameter Bench Photometer for laboratories: $2 \mathrm{ml}$ of sample were added to an oxidizing chromatic acid solution and digested for $2 \mathrm{~h}$ at $150^{\circ} \mathrm{C}$. After cooling, the color of the sample varied from orange to green.

The Folin-Ciocalteau reagent was used to determine the total polyphenol (Pp) content; this reagent is a solution of complex polymer ions formed from phosphomolybdic and phosphotingstic heteropoly acids. It oxidizes phenolates, reducing the heteropoly acids to a Mo-W complex at alkaline $\mathrm{pH}$, resulting in a blue color. The total content of polyphenols was estimated spectrophotometrically (Beckman DU 640) at $730 \mathrm{~nm}$, with gallic acid as standard. The equation was: $\mathrm{Pp}\left(\mathrm{mgl}^{-1}\right)=$ Abs/2.33855 D

$\mathrm{D}=$ dilution factor

\section{RESULTS AND DISCUSSION}

Data on the growth of the aquatic fern (AzollaAnabaena azollae symbiosis) outdoors in the climatic conditions of Florence are reported in Table 2. The productivities achieved in the $25 \mathrm{~m}^{2}$ pond were similar to those reported by Carlozzi et al. (1986) for a $100 \mathrm{~m}^{2}$ pond. The highest yield $(13.2 \mathrm{~g}$ dry weight (d.w.) $\mathrm{m}^{-2} \mathrm{~d}^{-1}$ ) was achieved in July; the average productivity was $10.3 \mathrm{~g}$ (d.w.) $\mathrm{m}^{-2} \mathrm{~d}^{-1}$.

Table 2

Yield and growth rate of Azolla filiculoides achieved outdoors in a maxi-pond of $25 \mathrm{~m}^{2}$. The average planting density was $50 \mathrm{~g}$ (dry weight) $\mathrm{m}^{-2}$.

\begin{tabular}{ccc}
\hline Months & $\begin{array}{c}\text { Productivity } \\
\text { [g (d.w.) } \mathbf{~ m}^{-2} \mathbf{~ d}^{-1} \text { ] }\end{array}$ & $\begin{array}{c}\text { Growth rate } \\
\mathbf{( d}^{-1} \mathbf{)}\end{array}$ \\
\hline July & 13.2 & 0.235 \\
August & 10.1 & 0.183 \\
September & 7.7 & 0.144 \\
\hline
\end{tabular}

Physico-chemical analyses of the two OMWw showed that they were dark acidic wastes with high levels of organic matter and polyphenols. The TS OMWw was darker than the CS OMWw, and the COD and polyphenol levels were respectively $107 \%$ and $68.5 \%$ higher in the TS OMWw. According to Ranalli (1992), phenolic compounds are the pigments responsible for the dark color of OMWw.

To determine the best OMWw/fresh-Azolla ratio (w/w) for the removal of organic compounds, four ratios were tested: 10:1, 5:1, 2:1 and 1:1.

The results for the Imhoff cones and columns were the same.
Figure 3 shows the Azolla adsorption of polyphenols at the four OMWw/fresh-Azolla ratios. Despite the different initial polyphenol concentrations in the two wastewater types (TS, CS), the proportional decrease in polyphenol content after Azolla treatment was the same. Figure 4 shows the polyphenol pull-down efficiency. The most effective OMWw/fresh-Azolla ratio was 5:1 in both OMWw types, and the highest values were $5 \mathrm{mg} \mathrm{I}^{-1}$ $\mathrm{g}(\text { Azolla })^{-1}$ in TS and $2.75 \mathrm{mg} \mathrm{I}^{-1} \mathrm{~g}(\text { Azolla })^{-1}$ in CS.

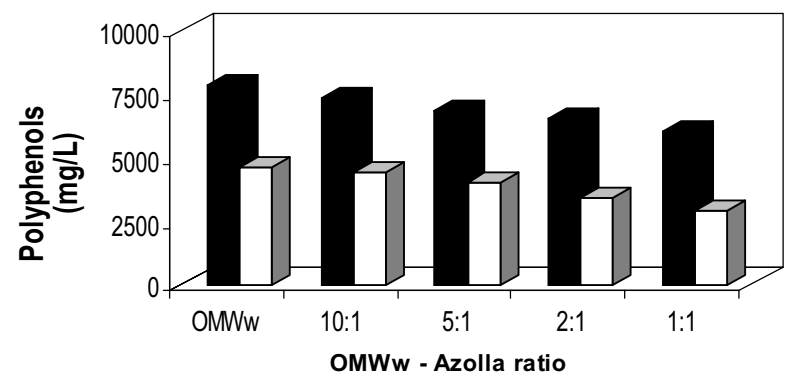

Figure 3

Polyphenol reduction in TS OMWw (black bars) and CS OMWw (white bars) as a function of the OMWw/fresh-Azolla ratio.

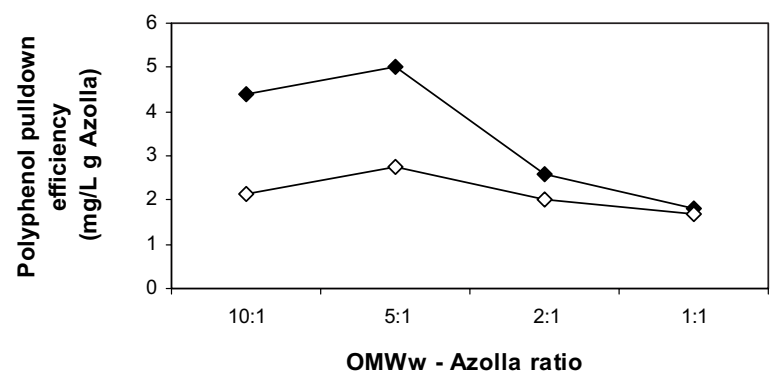

Figure 4

Polyphenol pull-down efficiency in TS OMWw $(\bullet)$ and CS OMWw $(\diamond)$ as a function of the OMWw/fresh-Azolla ratio.

The pattern of COD removal was similar (Fig. 5). The optimal OMWw/fresh-Azolla ratio was 5:1 (Fig. 6). This ratio was chosen for the experiments, since it always gave the highest COD pull-down efficiency in both types of OMWw $\left(70 \mathrm{mg} \mathrm{I}^{-1} \mathrm{~g}(\text { Azolla })^{-1}\right.$ in TS and $57 \mathrm{mg} \mathrm{l}^{-1} \mathrm{~g}(\text { Azolla })^{-1}$ in CS). A comparison of Figures 3 and 5 with Figures 4 and 6 respectively shows that the total organic matter content (polyphenols and COD) adsorbed by the Azolla biomass increased as the OMWw/Azolla ratio decreased, while the COD and polyphenols

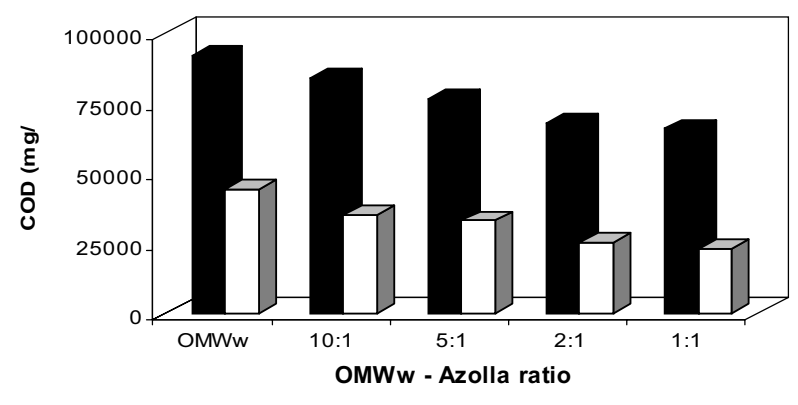

Figure 5

COD reduction in TS OMWW (black bars) and CS OMWW (white bars) as a function of the OMWw/fresh-Azolla ratio. 


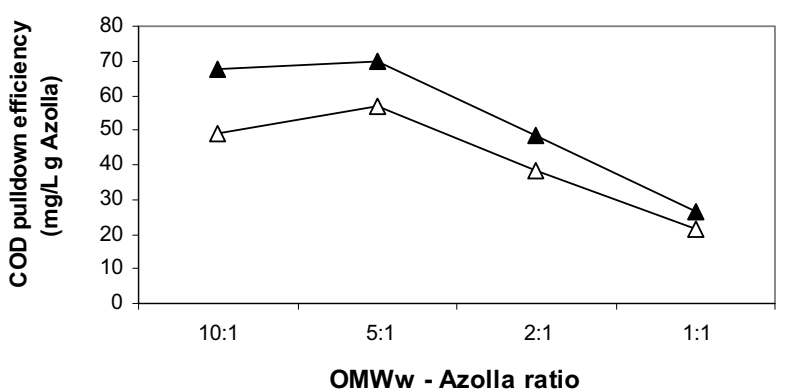

Figure 6

COD pull-down efficiency in TS OMWw $(\mathbf{\Delta})$ and CS OMWw $(\Delta)$ as a function of the OMWw/fresh-Azolla ratio.

adsorbed per unit of biomass dry weight decreased. This behavior was similar to that observed by Itho et al. (1975) in heavy metal removal by plant and microbial biomasses; the authors supposed that the dependence of adsorption on cell density was probably due to electrostatic interactions among binding sites, as more ions are adsorbed on the cell when cell distances are greater. Cohen-Shoel et al. (2002) reported a correlation between metal adsorption and the availability of carboxyl groups of galacturonic acid, the principal constituent of pectin. They used methylation, demethylation of carboxyl groups and pectinase treatment to demonstrate that the pectin of the Azolla cell wall is the major metal binding site. Likewise, lignin and cellulose, the major constituents of tree ferns, were mainly responsible for the adsorption of a basic dye by those plants, because of the availability of their polar functional groups (Newman, 1997; Ho et al., 2005). In our study, the adsorption efficiency of the 10:1 OMWw/fresh-Azolla ratio was similar to that of the 5:1 ratio. This was probably the result of the saturation of binding sites above a certain concentration of the organic compounds.

A single biofilter with the Azolla matrix was considered insufficient to achieve an effective pulldown of organic compounds (polyphenols and COD) in OMWw. Thus, we tested a new process using five Imhoff cones (biofilters) in series. The results of the sequential passages of the same OMWw are shown in Fig. 7a,b. The COD and polyphenol contents in the OMWw decreased progressively from the first to last cone. In the OMWw from the $5^{\text {th }}$ cone, COD was reduced to $52400 \mathrm{mg} \mathrm{l}^{-1}$ in TS and to $2300 \mathrm{mg} \mathrm{l}^{-1}$ in CS. The polyphenols decreased to $3610 \mathrm{mg} \mathrm{l}^{-1}$ in TS and to $1351 \mathrm{mg} \mathrm{l}^{-1}$ in CS.

Figure 8 shows the percentage of decrease in polyphenols and COD in the TS and CS OMWw after passing through the series of five Imhoff cones. Polyphenols decreased by $53 \%$ in TS and by $65 \%$ in CS. COD decreased by $52 \%$ in TS and $95 \%$ in CS. The higher COD pull-down percentage in the CS OMWw was probably due to the complete saturation of the binding sites after treatment. In the TS OMWw, the initial COD concentration was probably higher than the number of available binding sites on the Azolla cell wall.
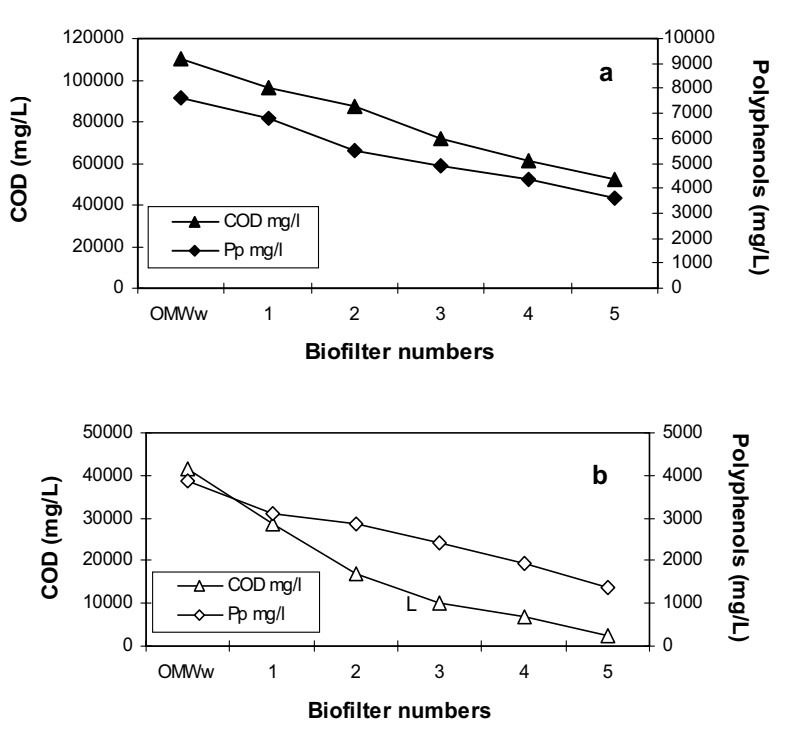

Figure 7

COD and polyphenol $(\mathrm{Pp})$ removal in OMWw after five passages through fresh-Azolla biomass packed into Imhoff cones: traditional system (a); continuous system (b).

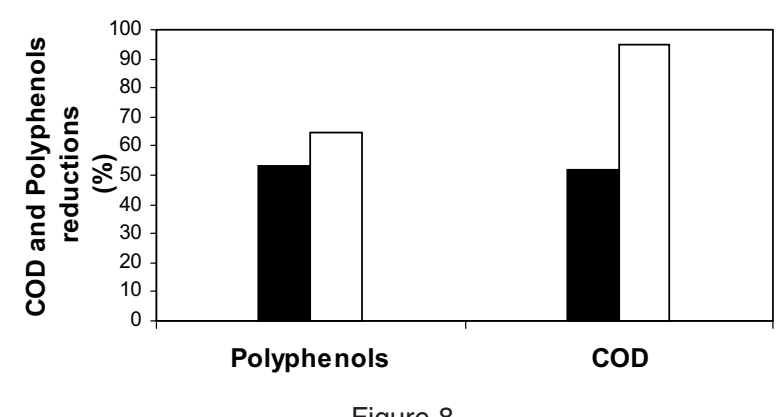

COD and polyphenol percentage decrease in TS OMWw (black bars) and CS OMWw (white bars).

The color intensity of the TS and CS OMWw decreased by $45 \%$ and $52 \%$ respectively after Azolla treatment (data not shown). The remaining substrate color was mainly due to highly polymerized phenolic compounds, which are not readily absorbed by Azolla.

It is noteworthy that the organic matter adsorption capacity seems to depend on the type of organism used. Beccari et al. (2002) compared the COD removal obtained with activated sludge with that achieved with a co-culture of aerobic bacteria (Bertin et al., 2001) using the same oil mill effluent. The total COD pull-down percentages were $86.5 \%$ and $52.4 \%$ respectively.

Gardea-Torresdey et al. (1995a; 1995b) used fresh and silica-immobilized Medicago sativa (alfalfa) for heavy metal adsorption, and they successfully removed copper and nickel from aqueous solutions. They established that a $\mathrm{pH}$ of 56 was optimal for heavy metal binding to alfalfa tissues. Acidic $\mathrm{pH}$ was probably essential because it made the carboxyl groups of the alfalfa cell wall available for metal binding.

Results of the comparison of the biofiltration properties of alfalfa and Azolla for OMWw 
purification are shown in Fig. 9. OMWw was treated with alfalfa without changing the $\mathrm{pH}$ and the results were compared with those of Azolla removal of $\mathrm{COD}$ and polyphenols at the same $\mathrm{pH}(4.5-5.1)$. In these conditions, there was no reduction of either COD or polyphenols with the alfalfa treatment. This confirms the high affinity and binding capacity of both COD and polyphenols to Azolla biomass. Therefore, Azolla has great potential for bioremediation because it is easily obtained at low cost.

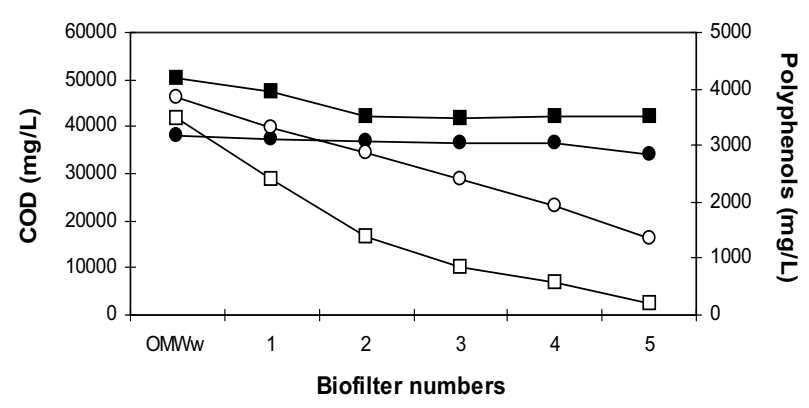

Figure 9

Comparison of COD $(\square)$ and polyphenol (o) abatement in OMWw after biofiltration with Azolla (open symbols) and alfalfa (closed symbols).

\section{CONCLUSIONS}

This preliminary study demonstrates the role of Azolla in reducing the organic load of polyphenols and COD in OMWw. This finding is enhanced by the negative results obtained with alfalfa.

Azolla production is easy and cheap because it can grow in a culture medium without nitrogen thanks to the $\mathrm{N}_{2}$-fixing cyanobacteria Anabaena azollae living in cavities on the dorsal of the fern's leaves.

These aspects, together with the ability of Azolla biomass to remove both polyphenols and COD from OMWw, provide a new low-cost strategy for OMWw bioremediation and polyphenol recovery.

The treated wastewaters are not toxic and the effluent appears to be environmentally safe and suitable for agricultural irrigation, providing the soil with organic matter and potassium.

Research is in progress to investigate the mechanism by which Azolla biomass removes COD and polyphenols from OMWw.

\section{ACKNOWLEDGMENTS}

The authors acknowledge the partial financial support of this project by the European Community (CE 1334/02).

\section{REFERENCES}

Beccari M, Crucci G, Lanz AM, Majone M, Petrangeli Papini M. 2002. Removal of molecular weight fractions of COD and phenolic compounds in an integrated treatment of olive oil mill effluents. Biodegradation 13, 401-410.

Bertin L, Majone M, Di Gioia D, Fava F. 2001. An aerobic fixed-phase biofilm reactor system for the degradation of the low molecular weight aromatic compounds occurring in the effluents of anaerobic digestors treating olive mill wastewaters. J. Biotechnol 87, 161-177.

Carlozzi P, Favilli F, Pushparaj B, Balloni W. 1986. Biomass production and $\mathrm{N}_{2}$-fixation by Azolla filiculoides in outdoor mass culture. In: Proceedings of the 1986 International congress on renewable energy sources, Ed. S. Terol; Vol. 1. Madrid, Spain, 18-23 May.

Civantos L. 1995. Evoluciòn de la Superficie del Olivary de las Producciones de Aceite de Oliva en España. Olivae 59, 18.

Cohen-Shoel N, Ilzycer D, Gilath I, Tel-Or E. 2002. The involvement of pectin in $\mathrm{Sr}^{2+}$ biosorption by Azolla. Water, Air, Soil Pollut.135, 195-205.

Cox L, Becker A, Celis R, Lopez R, Hermosin NRC, Cornejo J. 1996. Movement of clopyralid in a soil amended with olive oil mill wastewater as related to soil porosity. Fresen. Environ. 3-4, 167-171.

Gardea-Torresdey JL, Tiemann KJ, Gonzalez JH, CanoAnguillera I, Henning JA, Townsend M. 1995a. Ability of Medicago Sativa (alfalfa) to remove nickel ions from aqueous solution. Proceedings of the $10^{\text {th }}$ Annual Conference on Hazardous Waste Research, pp 209217.

Gardea-Torresdey JL, Tiemann KJ, Gonzalez JH, Henning JA, Townsend MS. 1995b. Removal of copper ions from solution by silica-immobilized Medicago Sativa (alfalfa). Proceedings of the $10^{\text {th }}$ Annual Conference on Hazardous Waste Research, pp 239-248.

Hamdi M, Garcia LJ. 1993. Anaerobic digestion of olive mill wastewaters after detoxification by Aspergillus niger. Process. Biochem. 28, 155-159.

Ho YS, Chiang TH, Hsueh YM. 2005. Removal of basic dye from solution using tree fern as biosorbent. Process. Biochem. 40, 119-124.

Itho M, Yuasa M, Kobajashi T. 1975. Adsorption of metal ions on yeast cells at varied cell concentrations. Plant Cell Physiol. 16, 1167-1169.

Jauneau A, Quentin M, Driouich A. 1997. Microheterogeneity of pectin and calcium distribution in the epidermal and cortical parenchyma cell wall of flax hypocotil. Protoplasma 189, 9-19.

Kamnev A, Colina M, Rodriguez J, Ptichkiina NM, Ignatov VV. 1998. Comparative spectroscopic characterization of different pectins and their sources. Food Hydrocolloid 12, 263-271.

Lopez R. 1992. Land treatment of liquid wastes from the olive oil industry (Alpechin). Fresen. Environ. Bull. 1, 129-134.

Lumpkin TA, Plunknet DL. 1980. Azolla: botany, physiology and use as green manure. Econ. Bot. 34, 111-153.

Marques IP. 2000. Anaerobic digestion treatment of olive mill wastewater for effluent re-use in irrigation. Desalination 137, 233-239.

Montedoro G, Servili M, Baldioli M, Miniati E. 1992. Simple and hydrolyzable phenolic compounds in virgin olive oil. 1. Their extraction, separation and quantitative and semiquantitative evaluation by HPLC. J. Agric. Food. Chem. 40 (9), 1571-1576.

Monteoliva-Sanchez M, Incerti C, Ramos-Cormenzana A, Paredes C, Roig A, Cegarra J. 1996. The study of the aerobic bacterial microbiota and the biotoxicity in 
various samples of olive mill wastewater (alpechin) during their composting process. Int. Biodeterior. Biodegrad 38, 211-214.

Newman RH. 1997. Crystalline forms of cellulose in the silver tree fern Cyanthea dealbata. Cellulose 4, 269279.

Paredes C, Bernal MP, Roig AJ, Cegarra J, SanchezMonedero MA. 1996. Influence of the bulking agent on the degradation of olive-mill wastewater sludge during composting. Int. Biodeterior. Biodegrad 38, 205-210.

Ranalli A. 1992. L'effluent des huiles d'olives: proposition en vue de son utilisation et de son épuration. Références aux norms italiennes en la matiére. $1^{\text {re }}$ Olivea 37, 30-39.

Schols HA, Reitsma JCE, Voragen AGJ, Pilnik W. 1989. High-performance ion exchange chromatography of pectins. Food Hydrocolloid 3, 115-121.
Sela M, Tel-Or E. 1988. Localization and toxic effects of cadmium, copper and uranium in Azolla. Plant Physiol. 88, 30-36.

Spandre R, Dellomonaco G. 1996. Polyphenols pollution by olive mill wastewaters, Tuscany, Italy. J. Environ. Hydrol. 4, 1-13.

Tardàguila J, Montero $\mathrm{F}$, Olmeda $\mathrm{M}$, Alba J, Bernabèu R. 1996. Analisis del Sector del Aceite de Oliva. Alimentaciòn, Equipos y Tecnologia Abr. 22.

Visioli F, Vincieri FF, Galli C. 1995. Waste waters from olive oil production are rich in natural antioxidants. Experientia 5, 32-34.

Yesilada O, Sik S, Sam M. 1997. Treatment of olive oil mill wastewater with fungi. Tr. J. of Biology 23, 231-240.

Recibido: Marzo 2006 Aceptado: Octubre 2006 